\title{
Nákupní zvyklosti spotřebitelů
}

\author{
Denisa Mikulová \\ Univerzita Tomáše Bati ve Zlíně, Fakulta managementu a ekonomiky \\ Mostní 5139, 76001 Zlín, Česká republika \\ denisamikulova@seznam.cz
}

\begin{abstract}
Anotace: Tento článek si dává za cíl propojit téma nákupní zvyklosti spotřebitelů a online prostředí. Těžištěm příspěvku je rešerše, průzkum literárních a také vědeckých pramenů. Díky rychlému rozvoji informačních technologií v posledních letech internet nejen změnil způsob života lidí, ale ovlivnil také obchodní aktivity. Rychlý nárůst e-služeb narušuje tradiční obchodní model a mění nákupní zvyklosti spotřebitelů. Spotřebitelé mohou nakupovat produkty prostřednictvím online nakupování kromě fyzických maloobchodních prodejen; homogenita produktů prodávaných na internetu však představuje hrozbu cenové války. Výsledkem je, že online prodejce musí navázat a udržovat dlouhodobá partnerství se svými zákazníky, aby vytvoriil udržitelné konkurenční výhody, a e-služby mají velký potenciál k dosažení tohoto cíle. Podniky by proto měly věnovat velkou pozornost zlepšování kvality služeb pro své zákazníky.
\end{abstract}

\section{1 Úvod}

V roce 2015 přesáhl asijský trh online nakupování 13,3 miliardy USD a je mnohem vyšší než všechny národní obchodní domy 9 miliard USD, prodejna 8,1 miliardy dolarů a supermarkety 4,76 miliardy USD. V roce 2016 presáhl trh internetového nakupování 16,6 miliardy USD. Tato informace znamená, že neustálý růst online nakupování se stal středem zájmu podniků. Rychlý nárůst e-služeb narušuje tradiční obchodní model a mění nákupní zvyklosti spotřebitelů. Kvalita služeb bude výrazně ovlivňovat nákupní záměr spotřebitelů a dobrá kvalita služeb povede k chování zákazníků. Kvalita služeb je hlavním faktorem, který ovlivňuje důvěru a spokojenost spotřebitelů s webem.

\section{Internetový prodej}

$\mathrm{Na}$ základě literatury [1] vzhledem k vysoce konkurenčnímu a rychle se měnícímu prostředí internetový prodejce stále více zdưrazňuje kvalitu služeb, nejen jako konkurenční zbraň, ale také pro přežití. Košturiak [2] uvedl, že „webové stránky rázně rostou a nevyhnutelně musí spotřebitelům poskytovat vysoce kvalitní služby, aby vytvořily vynikající zkušenosti a získaly srdce zákazníků a vytvořily si vzájemně prospěšný a dlouhodobý vztah." Jiang [3] rovněž zdůraznil, „v důsledku toho kvalita elektronických služeb pritahuje prioritní obavy." 


\subsection{Kvalita služeb}

Na základě literatury [4] mají služby čtyři vlastnosti: nehmotnost, různorodost, nelze je skladovat a nedělit. Ačkoli je pro definování a měření kvality služeb obtižné definovat a měřit čtyři vlastnosti, existují tři reprezentativní metody měření kvality služeb.

\section{SERVQUAL}

Podle Falka [5] „je dobrým a široce používaným prostředkem pro měření kvality služeb. Jádrem služby SERVQUAL je paradigma nesouhlasu, což je nesoulad generovaný, když se vnímaná kvalita služby liší od kvality očekávané zákazníky. Pokud príiatá kvalita služeb překoná očekávání zákazníků, budou považovat kvalitu služeb vysokou, naopak pokud je kvalita přijaté služby horší než jejich očekávání, zákazníci se domnívají, že obdrželi špatnou kvalitu služby."

\section{Kvalita elektronických služeb}

Humair [6] použil tři hlavní dimenze - kvalitu prostředí, kvalitu procesu a kvalitu výsledku $\mathrm{k}$ vytvoření hierarchického modelu pro měření kvality online služeb. Kvalita prostředí odpovídá vzhledu uživatelského rozhraní, kvalita procesu (nebo kvalita dodávky) označuje interakci spotřebitelů $s$ webovou stránkou během servisního procesu (jako je vyhledávání informací a výběr produktu), a kvalita výsledku se týká měření výsledku služby po príijetí služby [7]. Remondes [8] navrhl, aby kvalita služeb elektronického obchodu byla konstruována pomocí tří následujících složek: kvalita životního prostředí, kvalita dodávky a kvalita výsledku.

\section{Index výkonu webových stránek}

$\checkmark$ prostředí online nakupování je klíčovým ukazatelem pro měření kvality online služeb hodnocení výkonu webové stránky. Chaffey [9] poukázal na osm prvků výkonu webových stránek: „dostupnost systému, snadnost použití, užitečnost, navigační výzva, design webových stránek, kvalita obsahu, radost a důvěra." [2] Dostupnost systému: Týká se hlavně technologických funkcí a výkonu webové stránky; to znamená, že informační technologie použitá na webu může uživatelům poskytnout dobré prostředí prohlížeče; uživatelé mohou také co nejdříve opustit nereagující nebo pomalu načítající web. Snadné použití: Uživatelé mohou snadno používat web. [7] Užitečnost: Web může uživatelům poskytovat užitečné informace. Navigační výzva: Celková struktura webu je jasná, aby uživatelé mohli snadno procházet webem. (5) Návrh webových stránek: Jedná se zejména o vnější vzhled webových stránek, včetně barevné kombinace, písma a stylu, obrázků, audio, zvuku atd. Kvalita obsahu: Webové stránky mohou poskytovat přesný a praktický produkt. informace. Potěšení: Jedná se zejména o interaktivní potěšení mezi uživateli a webem. [1] Důvěra: Webové stránky mohou uživatelům poskytnout pocit bezpečí, aby se mohli znovu vrátit. 


\subsection{Závazek}

Koncept závazku zavádějí marketingoví vědci a rozšiřuje se na tržní pole a Ize jej vysledovat až k organizačnímu chování, loajálnímu vztahu mezi zaměstnanci a organizací. Závazek je povinný prvek marketingu. Kim [10] věíil, že „různé motivace by způsobily různé závazky $v$ oblasti marketingu. Závazek má proto trojí význam: afektivní, přetrvávající a normativní závazek."

\section{Afektivní závazek}

V oblasti marketingu znamená pojem afektivního závazku, že jedna strana udržuje obchodní vztah, protože se jim líbí jejich obchodní partner a partnerství si užívají. Afektivní závazek Ize také považovat za psychologický stav. Spotřebitelé jsou spojeni s obchodními partnery psychologickým přijetím a připoutáním [10]. Kotler [11] uvedli, že „s postupem času spotřebitelé doufají, že budou rozvíjet a posilovat mezilidské vztahy, aby dosáhli důvěrnosti, přátelství a osobní důvěry. Celkově je afektivní závazek založen na přijemných nákupních zkušenostech nebo na vynikajících službách, takže dochází k pozitivním poklesưm a zákazníci udržuji spojení se svými partnery."

\section{Závazek k pokračování}

Kawaf [12] se domníval, že „vytvoření závazku k pokračování je důsledkem vysokých nákladů na přeměnu, nedostatečného nahrazování a vysoké závislosti." Jedná se tedy o závazek vytvořený po výpočtu nákladů a přínosů. Pokud se spotřebitelé domnívají, že ukončení ekonomických nákladů a sociálních nákladů, jakož i nedostatek volby ukončit vztah $s$ partnerem, je př́liš mnoho, bude i nadále generován závazek $\mathrm{k}$ pokračování [2]. Předpokládá se, že vzhledem k omezení partnerství je vztah udržován prostřednictvím negativních motivací [11]. Přestože se partner snaží navázat pozitivní spolupráci, spotřebitelé by stále byli omezeni vztahem a nebyli schopni odejít. Stručně řečeno, v príípadě, že bude vytvořen trvalý závazek, spotřebitelé by si udrželi vztah s partnerem, avšak po ukončení spolupráce bude vyplacena vyšší cena.

\section{Normativní závazek}

Zákazníci se domnívají, že mají povinnost obchodovat s partnerem, takže partnerství musí být mezi nimi udržováno [4]. Hlavním dủvodem udržení vztahu je to, že zákazníci věří, že získané výhody jsou založeny na principu reciprocity [13]. Zákazníci se musí zavázat $k$ partnerovi, zpětná vazba generovaná partnerovi, která by nakonec vytvořila etiku a povinnost $v$ myslích zákazníků udržovat partnerství. Normativní závazek je tedy psychologické propojení vytvořené s partnerem, které zákazníkům umožňuje udržovat vztah.

\subsection{Věrnostní záměr}

Při zkoumání související literatury vědci vysvětlili loajalitu prostřednictvím různých perspektiv chování a přistupu, takže byly vytvořeny různé definice. Nelze však plně analyzovat loajalitu zákazníků diskutováním pouze o postoji nebo chování zákazníků. Boateng [14] uvedl, že „loajalita pramení z uctivých 
postojů zákazníků $\mathrm{k}$ nákupním webům; zákazníci tak opakují své nákupní chování a záměr navštěvovat a zpětně nakupovat na webových stránkách je opět a pokračuje v budoucnosti." Kromě toho je takový koncept použitelný pro elektronické obchodování [8]. Pokud je elektronická loajalita vyšší, bude v budoucnu také možnost opětovného nákupu produktu nebo služby poskytované podnikem vyšší, takže zisk e-Retailer by se také zvýšil. Věrnostní záměr spotřebitelů by měl tedy zahrnovat úroveň postoje i chování.

\subsection{Záměr obhajoby}

Advokace se týká ochoty spotřebitelů pozitivně posoudit produkt nebo službu poskytovanou dodavatelem a důrazně je doporučit ostatním spotřebitelům. Toto je běžně známé jako pozitivní slovo z ústního marketingu. Pokud se spotřebitelé domnívají, že je s poskytovatelem služeb vytvořen pohodlný vztah, obhajují poskytovatele služeb [15] a doporučují produkty nebo služby prátelưm nebo známým. Chen [16] tvrdil, že „obhajoba zahrnuje propagandu a pozitivní ústní projevy prosazované pro podniky zákazníky, kteří měli dobré zkušenosti během takového náročného procesu. Poskytují tedy pozitivní hodnocení, obhajují a poskytují bezplatnou reklamu pro podnik."

Dá se tedy říct, že záměr advokacie je vyjádřením loajality zákazníků. Obchodní administrátoři mohou měřit ochotu poskytovat pozitivní doporučení hodnocením zákazníků [6].

\subsection{Ochota zaplatit více (WTPM)}

Je považována za reakci zákazníka, která souvisí s loajalitou. Pokud mají zákazníci zvláště úzký vztah s jedním konkrétním dodavatelem, zákazníci by byli ochotni zaplatit vyšší ceny, pokud dodavatel poskytuje cenný produkt [17]. Chen [18] uvedl, že „WTPM je záměrem zákazníků; to znamená, že zákazníci upřednostňuji určitého dodavatele před jinými obchody, budou ochotnější koupit produkt nebo službu poskytovanou takovým dodavatelem." Pokud jde o elektronický obchod, Boateng [14] tvrdil, že „WTPM odkazuje na ochotu zákazníků platit vyšší ceny za udržení vztahu s elektronickým maloobchodníkem." Stručně řečeno, tato studie věří, že WTPM je preferencí zákazníků pro určité dodavatele a ochota platit vyšší ceny za nákup nebo použití produktu nebo služby poskytované těmito dodavateli. Na základě výše uvedeného přehledu literatury tato studie nejprve stanoví strukturu výzkumu a poté vyvozuje hypotézu výzkumu. Poté jsou pro každou z proměnných stanoveny provozní definice a jsou stanoveny položky měření. Nakonec je systematicky plánován výzkumný záměr, včetně studijních objektů, návrhu dotazníku, analýzy dat a analytických metod. [14]

\section{Zapojení webu do firemního marketingu}

Podle Čichovského [17] ,je web (ve smyslu webových stránek) v dnešní době jedním ze základních marketingových nástrojů firmy." Neodmyslitelně už se zařadil hned do několika složek marketingového mixu - přinejmenším do 
oblasti propagace a distribuce. U mnoha firem je ale na internetu značně závislý i samotný produkt a jeho cenová politika a $v$ takovém prípadě je tedy marketingový mix webem ovlivněn v plné šíri. Když mluvíme o zapojení webu do firemního marketingu, měli bychom se blíže zaměřit na jeho specifickou část - internetový marketing. Právě z pohledu internetového marketingu Ize na webové stránky pohlížet dvěma způsoby, z nichž každý má své zastánce i odpưrce:

1. Webové stránky jakožto součást internetového marketingu a jeden z internetových propagačních kanálů.

2. Webové stránky jako samostatná entita, $\mathrm{k}$ jejiž propagaci internetový marketing slouží.

Je očividné, že bez internetových stránek už se dnes neobejde marketing téměř žádné firmy. [17]

Jako příklad uvádím konkurenční analýzu pro e-shop s potravinami www.rohlik.cz.

Takto by mohl vypadat výstup konkurenční analýzy pro webové stránky www.rohlik.cz, který popisuje tabulka 1. Konkrétní údaje zjištované o jednotlivých e-shopem s potravinami je třeba zvolit podle účelu analýzy a jejího předpokládaného dalšího využití.

Tabulka 1 - Konkurenční analýza e-shopů

\begin{tabular}{|c|c|l|c|c|c|}
\hline $\begin{array}{c}\text { Online } \\
\text { potraviny }\end{array}$ & \multicolumn{1}{|c|}{ URL } & Dostupnost & S-rank & GTPR & $\begin{array}{c}\text { Počet } \\
\text { zpětných } \\
\text { odkazú }\end{array}$ \\
\hline Rohlík & https://www.rohlik.cz/ & $\begin{array}{l}\text { Praha, střední Čechy, } \\
\text { Brno,Pardubice, Hradec } \\
\text { Králové, Plzeň, Liberec, } \\
\text { Jablonec nad Nisou. }\end{array}$ & 65 & $6 / 10$ & 12382 \\
\hline Koš́ík & https://www.kosik.cz/ & $\begin{array}{l}\text { Praha, střední Čechy, } \\
\text { Pardubice, Chrudim, } \\
\text { Hradec Králové, Plzeň, } \\
\text { Liberec, Jablonec nad } \\
\text { Nisou, Ústí n. Labem, } \\
\text { Teplice. }\end{array}$ & 42 & 157 \\
\hline Tesco & https://www.itesco.cz/ & $\begin{array}{l}\text { Praha, střední Čechy a } \\
\text { okolí, Brno, Blansko a } \\
\text { okolí, Břeclav, Hodonín a } \\
\text { okolí, Pardubice, Hradec } \\
\text { Králové a okolí, Mladá } \\
\text { Boleslav a okolí }\end{array}$ & 40 & $5 / 10$ & 754 \\
\hline
\end{tabular}


Postup práce:

Při analýze byly využity následující dotazy ve vyhledávačích:

- nákup potravin online,

- potraviny do domu,

- dovoz jídla.

Jedním z hlavních zdrojů informací je pomocí vyhledávače Google nalezená stránka [19] u niž byla provedena analýza stránkových odkazů. Ke zjištění uvedených údajů vedlo jednak prozkoumání nalezených webů a dále:

- rozšiření Search Status pro prohlížeč Firefox ke zjištění Google Toolbar Page Ranku.

- H1.cz SEO rozšiření pro prohlížeč Firefox ke zjištění S-ranku.

- Dotaz „link:požadované URL“ pro zjištění počtu zpětných odkazů jednotlivých webů ve vyhledávači.

\section{Závěr}

Český zákazník je poměrně konzervativní, nedůvěřivý a orientovaný na cenu. Mnozí internetoví nakupující jsou ochotni zčásti obětovat své pohodlí (např. cesta do prodejny, na poštu) proto, aby ušetřili. Dále je stále přetrvávající nedůvěra nebo pocit nejistoty při nakupování přes internet a zejména při online platbách předem. Jako nejobtížnější krok ve vztahu k zákazníkovi se jeví první kontakt $s$ ním, respektive přesvědčit ho $\mathrm{k}$ jeho prvnímu nákupu. Pokud se toto internetovému obchodu úspěšně zdaří, včetně bezproblémové transakce zboží i platby, Ize s velkou pravděpodobností očekávat od stejného zákazníka opakované nákupy. Velká část zákazníků se orientuje podle vlastní zkušenosti nebo doporučení ostatních osob.

\section{Použitá literatura}

[1] Bednářová, D., Parmová, D. Malé a střední podnikání. České Budějovice: Jihočeská univerzita v Českých Budějovicích Ekonomická fakulta, 2010, 146 s. ISBN 978-80-7394-229-8.

[2] Košturiak, J., Frolík, Z. Štíhlý a inovativní podnik. Praha: Alfa Publishing, 2006, 237 s. ISBN 80-868-5138-9.

[3] Jiang, L., Jun, M., Yang, Z. Customer-perceived value and loyalty: how do key service quality dimensions matter in the context of B2C e-commerce? Service Business, 2016, Vol. 10, No. 2, p. 301-317.

[4] Hwangbo, H., Kim, Y. S., Cha, K. J. Recommendation system development for fashion retail e-commerce. Electronic Commerce Research and Applications, 2018, Vol. 28, p 94-101.

[5] Falk, M., Hagstenh, E. E-commerce trends and impacts across Europe. International Journal of Production Economics, 2015, Vol. 170, p. 357-369. 
[6] Humair, F. et al. E-commerce trade in invasive plants. Conservation Biology, 2015, Vol. 29, No. 6, p. 1658-1665.

[7] Hallikainen, H., Laukkanen, T. National culture and consumer trust in ecommerce. International Journal of Information Management, 2018, Vol. 38, No. 1, p. 97-106.

[8] Remondes, J. et al. On-line marketing, e-commerce and hospitality: study on the marking of hotels in internet market business-to-business. Revista Iberoamericana de Turismo (RITUR), 2015, Vol. 5, No. 1, p. 114-130.

[9] Chaffey, D., Ellis-Chadwick, F. Digital marketing. Pearson, UK, 2019.

[10] Kim, Y., Peterson, R. A. A Meta-analysis of Online Trust Relationships in Ecommerce. Journal of Interactive Marketing, 2017, Vol. 38, p. 44-54.

[11] Kotler, P. Marketing for nonprofit organizations. NJ: Prentice-Hall, 1982.

[12] Kawaf, F., Istanbulluoglu, D. Online fashion shopping paradox: The role of customer reviews and facebook marketing. Journal of Retailing and Consumer Services, 2019, Vol. 48, p. 144-153.

[13] Grossnickle, J. The handbook of online marketing research: knowing your customer using the Net. McGraw-Hill, Inc., 2001.

[14] Boateng, S. Online relationship marketing and customer loyalty: a signaling theory perspective. International Journal of Bank Marketing, 2019, Vol. 37, No. 1, p. 226-240.

[15] Jakubíková, D., Strategický marketing. Praha: Grada Publishing, 2008, 272 s. ISBN 978-80-247-2690-8.

[16] Chen, V. et al. E-commerce web site loyalty: A cross cultural comparison. Information Systems Frontiers, 2015, Vol. 17, No. 6, p. 1283-1299.

[17] Čichovský, L., Marketing konkurenceschopnosti. Praha: Radix, 2002, 270 s. ISBN 80-86031-35-7.

[18] Chen, V., Andree E. Facebook C2C social commerce: A study of online impulse buying. Decision Support Systems, 2016, Vol. 83, p. 57-69.

[19] Havlík, A. Velké srovnání českých online supermarketů: U koho se vyplatí nakupovat, jak řeší problémy s nákupem a kde mají největší výběr potravin? [online], 2018, [cit. 4. 8. 2019], https://refresher.cz/53759-Velke-srovnaniceskych-online-supermarketu-U-koho-se-vyplati-nakupovat-jak-resiproblemy-s-nakupem-a-kde-maji-nejvetsi-vyber-potravin?gdpr-accept=1 